\title{
Comparison of Salt Exclusion in Muscadine and Interspecific Hybrid Grapes Using a Greenhouse Screening Procedure
}

\author{
Danny Hillin ${ }^{1}$, Pierre Helwi ${ }^{2}$, and Justin J. Scheiner ${ }^{1}$
}

AdDitionAl INDEX wORDs. chloride, own-rooted, rootstock, sodium, Vitis rotundifolia

$\overline{\text { SUMMARY. Bunch grapes (Euvitis) are classified as moderately salt-tolerant. However, }}$ little is known about the salt tolerance of muscadine grapes (Vitis rotundifolia). The objective of this research was to evaluate the salt exclusion capacity of muscadine grapes relative to common bunch grape rootstocks and hybrid winegrapes using a greenhouse screening assay. In two separate experiments, 31 muscadine, six bunch grape rootstocks, and five hybrid winegrape cultivars were irrigated daily with a 25-mm sodium chloride salt solution for a period of $14 \mathrm{~d}$, followed by a destructive harvest to determine sodium $(\mathrm{Na})$ and chloride $(\mathrm{Cl})$ concentrations in root and shoot tissues. Generally, the muscadines studied exhibited a greater range of salt concentration relative to bunch grape rootstocks. Total tissue (shoot and root) salt varied by $250 \%$ and $430 \%$ across muscadines and by $180 \%$ and $190 \%$ across bunch grape rootstocks for $\mathrm{Na}$ and $\mathrm{Cl}$, respectively. Despite the wider range, muscadine grapes expressed significantly less leaf necrosis than the bunch grape rootstocks. The most effective salt-excluding muscadines, 'Janebell', 'Scuppernong', 'Late Fry', and 'Eudora', were not distinguishable from the bunch grape rootstocks ['Paulsen 1103' (1103P), 'Ruggeri 140' (140Ru), 'Schwarzmann', 'Millardet et de Grasset 101-14' (101-14 Mgt.), 'Millardet et de Grasset 420A' (420A), and 'Matador']. Overall, there was no discernable difference between the salt exclusion capacity of muscadine and bunch grapes. The hybrid winegrape 'Blanc Du Bois' displayed poor $\mathrm{Na}$ and $\mathrm{Cl}$ exclusion properties but showed only moderate leaf necrosis symptoms. In both experiments, 'Blanc Du Bois' accumulated more than two-fold higher root and shoot concentrations of $\mathrm{Na}$ and $\mathrm{Cl}$ compared with the best-performing rootstocks (1103P, 140Ru, 101-14 Mgt.), suggesting that 'Blanc Du Bois' could benefit from grafting if salinity is a limiting factor.

$\mathrm{H}$ igh soil salinity is an increasing challenge for global agriculture that affects a wide range of crops (Qadir et al., 2014). Grapes (Vitis sp.) are classified as moderately salt-tolerant, but high salinity can cause osmotic stress as well as specific ion toxicity (Downton, 1977a). Osmotic stress can result in decreased stomatal conductance and photosynthesis, leading

Received for publication 12 Apr. 2021. Accepted for publication 1 Sept. 2021.

Published online 1 November 2021.

${ }^{1}$ Department of Horticultural Sciences, Texas A\&M AgriLife Extension Service, HSFB, 2134 TAMU, College Station, TX 77843

${ }^{2}$ Texas A\&M AgriLife Extension Service, 1102 E. Drew Street, Lubbock, TX 79403

This study represents a portion of the thesis submitted by Danny Hillin for completion of a Master's degree.

J.J.S. is the corresponding author. E-mail: jscheiner@ tamu.edu.

This is an open access article distributed under the CC BY-NC-ND license (https://creativecommons. org/licenses/by-nc-nd/4.0/).

https://doi.org/10.21273/HORTTECH04627-20 to declining yield and overall vine health (Downton, 1977a; Prior et al., 1992; Walker et al., 2008). High cellular concentrations of specific salt ions, salt toxicity, can cause membrane damage, interfere with solute balance, and cause shifts in nutrient concentrations (Volkmar et al., 1998). Prolonged exposure to high internal concentrations of salts leads to leaf necrosis that begins at leaf margins and progresses inward (Walker et al., 2008), ultimately causing defoliation and vine death (Thomas, 2011). Salinity is particularly challenging for arid production regions that rely heavily on irrigation as well as areas with saline irrigation water sources (Ayars, 2013).

Bunch grapes (Euvitis) are more sensitive to $\mathrm{Cl}$ toxicity rather than $\mathrm{Na}$ (Downton, 1977a; Ehlig, 1960; Hickinbotham, 1933; Sykes, 1987); therefore, $\mathrm{Cl}$ exclusion, the ability of the plant to restrict uptake of $\mathrm{Cl}^{-}$from the soil and subsequent transport in the xylem to the shoot, has been widely studied in European winegrapes (Vitis vinifera) and bunch grape rootstocks as an indicator of salt tolerance (McEAlexander and Obbink, 1971; Antcliff et al., 1983; Downton, 1977a, 1977b; Sauer, 1968; Sykes, 1985, 1987; Teakle and Tyerman, 2010). European winegrapes generally are considered to be poor $\mathrm{Cl}$ excluders compared with rootstocks derived from winter grape (Vitis berlandieri) and sand grape (Vitis rupestris) (Downton, 1977a; Sauer, 1968). Previous studies have reported tissue $\mathrm{Cl}$ concentrations of more than 10-fold across grape species and interspecific hybrids (Bernstein et al., 1969; Downton, 1977a, 1977b). Therefore, salt exclusion is an important criterion for rootstock selection when salinity is perceived to be a limiting factor for production, and developing salttolerant rootstocks has been a priority for grape breeders in the United States (Fort and Walker, 2008).

Muscadines (Vitis rotundifolia) represent a species of grape native to the southern United States from Texas to Delaware. Unlike bunch grapes, which have 38 somatic chromosomes, muscadines have 40 chromosomes, and graft incompatibility has been reported (Winkler et al., 1974). Commercially, muscadines are grown on their own roots; however, little is known about their salt tolerance. The objective of this study was to compare the salt exclusion capacity of muscadines relative to common bunch grape rootstocks and interspecific winegrapes that are usually grown on their own roots using a rapid greenhouse assay.

\begin{tabular}{llll}
\hline $\begin{array}{l}\text { Units } \\
\text { To convert U.S. to SI, } \\
\text { multiply by }\end{array}$ & U.S. unit & SI unit & $\begin{array}{l}\text { To convert SI to U.S., } \\
\text { multiply by }\end{array}$ \\
\hline 29.5735 & $\mathrm{fl} \mathrm{oz}$ & $\mathrm{mL}$ & 0.0338 \\
2.54 & inch $(\mathrm{es})$ & $\mathrm{cm}$ & 0.3937 \\
28.3495 & $\mathrm{oz}$ & $\mathrm{g}$ & 0.0353 \\
1 & $\mathrm{ppm}$ & $\mathrm{mg} \cdot \mathrm{L}^{-1}$ & 1 \\
1 & $\mathrm{ppm}$ & $\mu \mathrm{g} \cdot \mathrm{g}^{-1}$ & 1 \\
0.9464 & $\mathrm{qt}$ & $\mathrm{L}$ & 1.0567 \\
$\left({ }^{\circ} \mathrm{F}-32\right) \div 1.8$ & ${ }^{\circ} \mathrm{F}$ & ${ }^{\circ} \mathrm{C}$ & $\left({ }^{\circ} \mathrm{C} \times 1.8\right)+32$
\end{tabular}


Salt tolerance in crop plants is a very active area of research (Munns and Gilliham, 2015; Munns et al., 2020; Zelm et al., 2020), and efforts to develop salt-tolerant grapevine rootstocks are ongoing (Cousins, 2005; Heinitz et al., 2014). Although advances in identifying species of grapes with superior salt exclusion properties (Heinitz et al., 2014) and mechanisms of salt tolerance have been made (Ahmad and Anjum, 2020; Das and Majumder, 2019; Gilliham and Tester, 2005; Henderson et al., 2014; Zelm et al., 2020), viticulture research has focused on bunch grapes, which are considered to be graft-incompatible with muscadines (Winkler at al., 1974). The goal of this study was to determine the relative salt tolerance of muscadines as well as several interspecific hybrid winegrapes that are frequently grown on their own roots by comparing them to rootstocks that have been previously characterized. A muscadine with superior salt tolerance would be better suited to grow at sites with high salinity or could potentially serve as a rootstock for other muscadines. The hybrid winegrapes presented here are most commonly grown on their own roots, although their salt tolerance is undocumented. The naturally high salt concentrations of groundwater from five major underground aquifers used for irrigation in Texas can lead to the buildup of high $\mathrm{Na}$ and $\mathrm{Cl}$ ion concentrations in the soil profile (George et al., 2011). Salt exclusion was evaluated at both the root (root-soil interface) and shoot levels (compartmentalization in roots) because both are recognized as mechanisms of salt tolerance (Munns and Tester, 2008). Leaf necrosis was measured as a relative indicator of tissue sensitivity to $\mathrm{Na}$ and $\mathrm{Cl}$.

Chloride has been the focus of most viticulture research due to its greater toxicity to grapes; however, in many other crops, Na has been identified as more important (Munns and Tester, 2008; Teakle and Tyerman, 2010). Because of the lack of research available, we chose to study both ions because neither has been reported for muscadines.

\section{Materials and methods}

Plant MATERIAL AND EXPERIMENTAL DESIGN. Two greenhouse experiments were conducted using a procedure described by Fort et al. (2013) to evaluate the relative $\mathrm{Na}$ and $\mathrm{Cl}$ exclusion capacity of muscadines and interspecific hybrid bunch grapes (Table 1). This procedure involves applying a known molar concentration of both $\mathrm{Na}$ and $\mathrm{Cl}$ to plant material in a neutral medium and then analyzing relative $\mathrm{Na}$

Table 1. Cultivar and parentage of grapes used for greenhouse salinity tests 1 and 2 to compare the salt exclusion capacity of muscadine and interspecific hybrid grapes. Parentage based on Clark (1997) and Riaz et al. (2008).

\begin{tabular}{|c|c|}
\hline Cultivar & Parentage \\
\hline \multicolumn{2}{|l|}{ Rootstocks } \\
\hline $\begin{array}{l}\text { Millardet et de Grasset } \\
\text { 101-14 (101-14 Mgt.) }\end{array}$ & Vitis riparia $\times V$. rupestris \\
\hline Paulsen $1103(1103 \mathrm{P})$ & $V$. rupestris $\times V$. berlandieri \\
\hline Ruggeri 140 (140Ru) & $V$. rupestris $\times V$. berlandieri \\
\hline $\begin{array}{l}\text { Millardet et de Grasset } \\
\quad 420 \mathrm{~A}(420 \mathrm{~A})\end{array}$ & $V$. berlandieri $\times V$. riparia \\
\hline Matador & $\begin{array}{l}\text { 101-14 Mgt. } \times 3-1 \mathrm{~A} \text { (Vitis mustangensis } \times \\
\quad \text { V. rupestris) }\end{array}$ \\
\hline Schwarzmann & $V$. riparia $\times V$. rupestris \\
\hline \multicolumn{2}{|l|}{ Hybrids } \\
\hline Black Spanish & Vitis sp. \\
\hline Blanc du Bois & Fla. D6-148 × 'Cardinal' \\
\hline Dunstan's Dream & Fla. W1521 × DRX 69-99 \\
\hline Southern Home & 'Summit' $\times$ Fla. P9-15 \\
\hline Victoria red & Ark. $1123 \times$ 'Exotic' \\
\hline \multicolumn{2}{|l|}{ Muscadines } \\
\hline Alachua & 'Fry' $\times$ 'Southland' \\
\hline Albemarle & 'Topsail' $\times$ 'Burgaw' \\
\hline Black Beauty & 'Fry' $\times 12-12-1$ \\
\hline Black Fry & 'Fry' $\times$ 'Cowart' \\
\hline Bountiful & 'Creek' $\times$ seedling of 'Topsail' \\
\hline Carlos & 'Howard' $\times$ NC11-173 ('Topsail' $\times$ 'Tarheel') \\
\hline Creek & Open pollinated seedling of 'San Monta' \\
\hline Darlene & $5-11-3 \times$ 'Carlos' \\
\hline Delicious & $\mathrm{AAl} 0-40 \times \mathrm{CD} 8-81$ \\
\hline Dixie & 'Topsail' $\times$ NC 28-193 ('Lucida' × 'Wallace') \\
\hline Dixiered & S. $44-6 \times$ S. $44-7$ \\
\hline Doreen & 'Higgins' $\times$ 'Dixie' \\
\hline Eudora & 'Fry' $\times$ 'Southland' \\
\hline Fry & Ga. 19-13 × USDA 19-11 \\
\hline Granny Val & 'Fry' $\times$ 'Carlos' \\
\hline Hall & 'Fry' $\times$ 'Tara' \\
\hline Higgins & 'Yuga' $\times$ white male pollinator \\
\hline Hunt & Flowers $\times$ white male muscadine \\
\hline Janebell & 'Fry' $\times$ 'Senoia' \\
\hline Late Fry & 'Fry' × 'Granny Val' \\
\hline Loomis & 'Creek' × US 15 \\
\hline Magnolia & $\begin{array}{l}{[(\text { 'Hope' } \times \text { 'Thomas') } \times \text { 'Scuppernong'] } \times} \\
\text { ('Topsail' } \times \text { 'Tarheel') }\end{array}$ \\
\hline Magoon & 'Thomas' × 'Burgaw' \\
\hline Pam & 5-11-3 × 'Senoia' \\
\hline Scuppernong & V. rotundifolia \\
\hline Southern Jewel & 'Granny Val' × DB-63 \\
\hline Southland & 'Thomas' $\times$ seedling of 'Topsail' \\
\hline Sterling & NC 50-55 × 'Magnolia' \\
\hline Supreme & 'Black Fry' $\times$ 'Dixieland' \\
\hline Triumph & 'Fry' × GA29-49 \\
\hline Welder & 'Dearing' $\times$ unknown \\
\hline
\end{tabular}

and $\mathrm{Cl}$ concentrations to establish a rank order of exclusion capability. The experiments were conducted during subsequent years from June to August in 2018 and 2019, under greenhouse conditions in College Station, TX. The experimental design was a randomized 
block with four replications. Each replication consisted of three potted vines. Plant material was acquired from the U.S. National Plant Germplasm Repository (Davis, CA), and vines were propagated by softwood cuttings under intermittent mist. After sufficient rooting $(28 \mathrm{~d})$, the plantlets were removed from mist and placed in square 0.65 -qt polypropylene pots containing $100 \%$ fritted clay media (Turface MVP; Turface Athletics, Buffalo Grove, IL) with a $\mathrm{pH}$ of 6.0. Pots were placed in flats with 4-inch spacing to increase air flow between plants. Vines were watered with reverse osmosis water (Series Rl8; Watts, North Andover, MA) at 48-h intervals and fertilized every $7 \mathrm{~d}$ with a $100-\mathrm{mg} \cdot \mathrm{L}^{-1}$ concentration of $21 \mathrm{~N}-$ $3.0 \mathrm{P}-5.8 \mathrm{~K}$ fertilizer (JR Peters, Allentown, PA) for a period of $28 \mathrm{~d}$. To equalize the quantity of leaf tissue across cultivars and replications, and to minimize direct contact between irrigation solution and leaves, vines were vertically staked and lateral shoot growth was removed $7 \mathrm{~d}$ before the initiation of a salt treatment. Starting on day 57 , a $25-$ mM sodium chloride $(\mathrm{NaCl})$ irrigation solution was applied daily by hand at a volume of $150 \mathrm{~mL}$ per pot for 14 consecutive days. A zero $\mathrm{NaCl}$ control was not included in this study because of cost and labor limitations.

Immediately after the completion of the salt treatment, vines were destructively harvested. Plants were rinsed with reverse osmosis water to remove any fritted clay media and surface contamination. Root and shoot materials were then separated at the base and oven-dried at $80^{\circ} \mathrm{C}$ for $48 \mathrm{~h}$. Root and shoot dry weight were subsequently determined with a balance (ME 204; Mettler Toledo, Columbus, $\mathrm{OH}$ ).

SODIUM AND CHLORIDE ANALYSIS. Dried root and shoot tissue samples of each replication were prepared and extracted separately for the $\mathrm{Na}$ and $\mathrm{Cl}$ analysis according to a rapid quantification method described by Iseki et al. (2017). Root and shoot samples were ground using a blade coffee grinder (Kitchen Aid, Benton Harbor, MI) until completely pulverized. Samples were then passed through a number 10 U.S.A. Standard Testing Sieve (The Murdock Co., Mundelein, IL) to ensure particle size uniformity. The $\mathrm{Na}$ and $\mathrm{Cl}$ were extracted from a $1.0-\mathrm{g}$ subsample of ground tissue using $50 \mathrm{~mL}$ of reverse osmosis water.
Samples were agitated with a vortex mixer (Thermo Fisher Scientific, Waltham, MA) at $2500 \mathrm{rpm}$ for $5 \mathrm{~min}$ and then centrifuged at $2900 g_{\mathrm{n}}$ for $5 \mathrm{~min}$ for extraction. Then, $20 \mathrm{~mL}$ of supernatant was removed and $\mathrm{Na}$ and $\mathrm{Cl}$ were tested directly using ion-selective electrodes (ROSS; Thermo Fisher Scientific). To ensure accuracy and precision, separate subsamples were collected from $10 \%$ of the root and shoot tissue samples and sent to the Texas A\&M Soil, Water, and Forage Testing Laboratory (College Station, TX) for comparison. The correlation coefficients of the two methods used to determine $\mathrm{Na}$ and $\mathrm{Cl}$ in root and shoot materials were 0.99 and 0.99 and 0.98 and 0.99 , respectively (data not shown).

LEAF NECROSIS RATINGs. Visual ratings of marginal leaf necrosis were recorded $3 \mathrm{~d}$ before destructive harvest. The percentage of marginal leaf necrosis was defined using the following five-tiered index described by Fort et al. (2013): $0=$ asymptomatic; $1=$ $1 \%$ to $25 \%$ of all leaves displaying any amount of necrosis symptoms; $2=$ $26 \%$ to $50 \% ; 3=51 \%$ to $75 \%$; and $4=76 \%$ to $100 \%$.

Statistical analysis. All data were analyzed using statistical software (JMP Pro version 10; SAS Institute, Cary, $\mathrm{NC}$ ). $\mathrm{Na}$ and $\mathrm{Cl}$ tissue concentration data were subjected to a one-way analysis of variance (ANOVA), and means were separated using the Tukey's honestly significant difference (HSD) test. Data from each test were not combined for analysis because of significant treatment $\times$ test interactions. The $\mathrm{Na}: \mathrm{Cl}$ ratio data were subjected to the Proc GLM procedure, whereby data from each test were combined for analysis and means were separated using Tukey's HSD test. Leaf necrosis ratings were subjected to a Kruskal-Wallace nonparametric analysis, and rootstock tissue $\mathrm{Na}$ and $\mathrm{Cl}$ data were subjected to ordinary least squares regression.

\section{Results and discussion}

During the first greenhouse assay, a $330 \%$ difference in total (root and shoot) $\mathrm{Na}\left[119 \mu \mathrm{g} \cdot \mathrm{g}^{-1}\right.$ for 'Millardet et de Grasset 101-14' (101-14 Mgt.) to $393 \mu \mathrm{g} \cdot \mathrm{g}^{-1}$ for 'Blanc Du Bois'] and a $470 \%$ difference in total plant $\mathrm{Cl}(196$ $\mu \mathrm{g} \cdot \mathrm{g}^{-1}$ for 'Scuppernong' to $919 \mu \mathrm{g}$. $\mathrm{g}^{-1}$ for 'Blanc Du Bois') were observed across the studied cultivars (Figs. 1-4). During the second experiment, the total
Na changed by $350 \%$ (137 $\mu \mathrm{g} \cdot \mathrm{g}^{-1}$ for 'Scuppernong' to $487 \mu \mathrm{g} \cdot \mathrm{g}^{-1}$ for 'Blanc $\mathrm{Du}$ Bois') and $\mathrm{Cl}$ changed by $950 \%$ $\left(152 \mu \mathrm{g} \cdot \mathrm{g}^{-1}\right.$ for 'Janebell' to $1447 \mu \mathrm{g}$. $\mathrm{g}^{-1}$ for 'Dunstan's Dream'). Although we were unable to attribute the wider range of total $\mathrm{Cl}$ observed during the second experiment to a specific factor or testing conditions, the ranges observed during both experiments were consistent with those of other studies of salt exclusion in grapevines (McEAlexander and Obbink, 1971; Antcliff et al., 1983; Bernstein et al., 1969; Downton, 1977a; Fort et al., 2013) (Figs. 2 and 4). Fort et al. (2013) reported no differences in leaf $\mathrm{Cl}$ concentrations among the strong $\mathrm{Cl}$-excluding rootstocks that we evaluated ['Schwarzmann', 101-14 Mgt., 'Paulsen 1103' (1103P), and 'Ruggeri 140' (140Ru)] using the same greenhouse procedure; however, they did observe a $200 \%$ to $500 \%$ difference between cultivars characterized as strong or weak excluders. More importantly, the rank order observed by Fort et al. (2013) was consistent with those of field studies of mature grapevines under conventional management.

The lowest total tissue Na concentrations were consistently observed in the rootstocks of 101-14 Mgt., $140 \mathrm{Ru}$, and $1103 \mathrm{P}$, and in the muscadines 'Scuppernong', 'Janebell', 'Darlene', 'Granny Val', 'Creek', 'Late Fry', and 'Eudora'. In contrast, the hybrid winegrapes 'Blanc Du Bois', 'Dunstan's Dream', and 'Victoria Red' and muscadines 'Doreen' and 'Hall' consistently accumulated the highest total $\mathrm{Na}$ concentrations. Several of these cultivars also showed similar responses to $\mathrm{Cl}$. The rootstock 101-14 Mgt. and muscadines 'Eudora', 'Janebell', 'Scuppernong', 'Late Fry', 'Darlene', and 'Granny Val' displayed the lowest $\mathrm{Cl}$ concentrations, whereas the hybrid grapes 'Blanc Du Bois' and 'Dunstan's Dream' consistently accumulated the highest $\mathrm{Cl}$ concentrations.

Because exclusion from shoots by compartmentalization in roots is a known mechanism of salt tolerance, the root-to-shoot concentration ratios were determined for both $\mathrm{Na}$ and $\mathrm{Cl}$ (Table 2). The hybrid winegrape 'Dunstan's Dream' had the highest ratios for $\mathrm{Na}(2.25)$ and $\mathrm{Cl}(3.70)$, whereas the those of other grapes ranged between 0.67 ('Southern Home') and 1.61 ('Black Spanish') and between 0.92 (101-14 Mgt.) and 


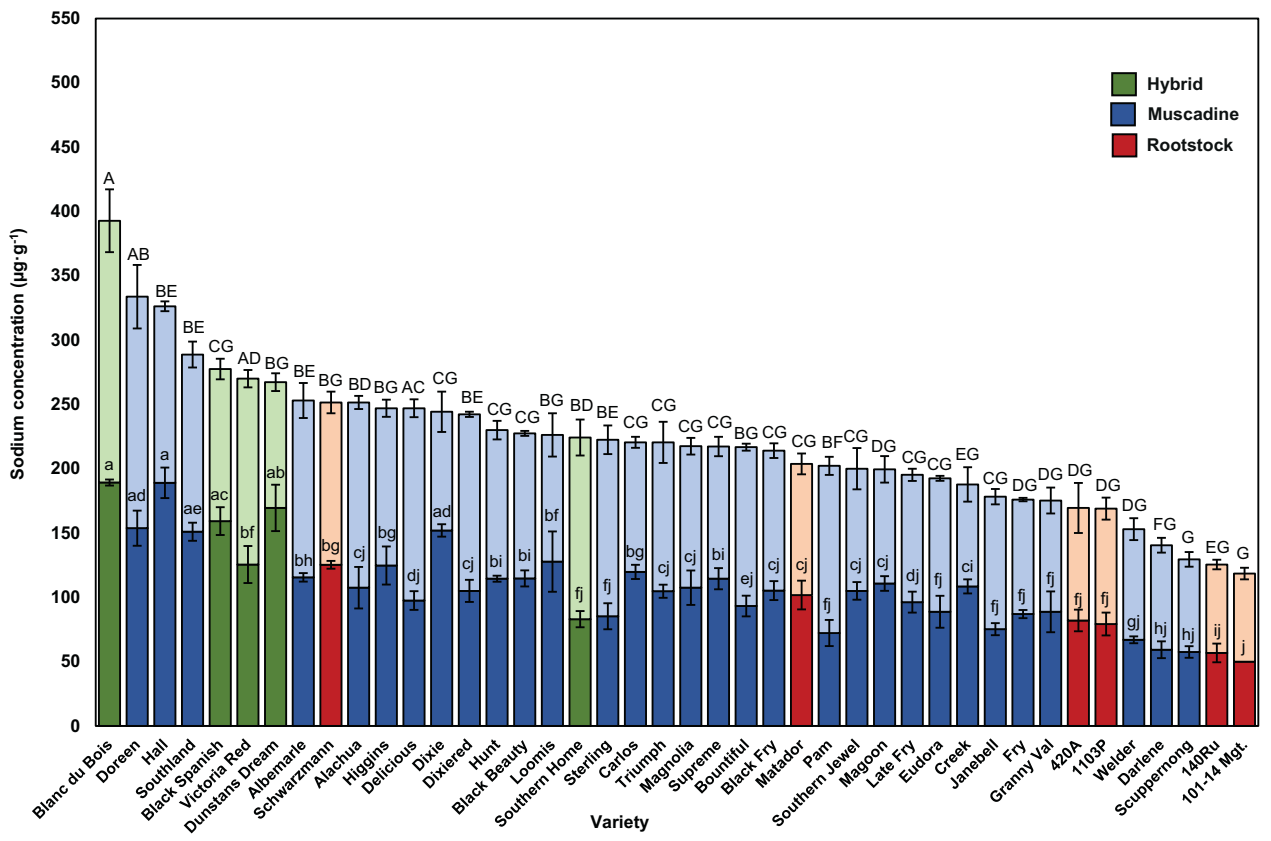

Fig. 1. Sodium concentrations in grape cultivar roots (shaded region) and shoots (unshaded region) during greenhouse test 1 after daily irrigation with a $25-\mathrm{mm}$ sodium chloride salt solution for $14 \mathrm{~d}$. Values are mean \pm SE. Top error bars indicate shoot values. Means indicated by different letters are significantly different at $P \leq 0.001$ via Tukey's honestly significant difference test; $1 \mu \mathrm{g} \cdot \mathrm{g}^{-1}=1 \mathrm{ppm}$.

2.09 ('Scuppernong'), respectively. Although 'Dunstan's Dream' appeared to display a greater degree of compartmentalization in the roots as compared with the other cultivars, it had one of the highest shoot concentrations of both ions, suggesting poor exclusion at the root level. 'Dunstan's Dream' is an interspecific hybrid with muscadine parentage; however, the graft compatibility between bunch grape $\times$ muscadine hybrids in this study ('Dunstan's Dream' and 'Southern Home') and muscadines is unknown.
The mean shoot concentration of $\mathrm{Na}$ in the six grape rootstocks studied was highly correlated $\left[R^{2}=0.98\right.$ and 0.88 , respectively (Supplemental Figs. 1 and 2)] with the root concentration observed during both tests, suggesting that exclusion at the shoot level did not

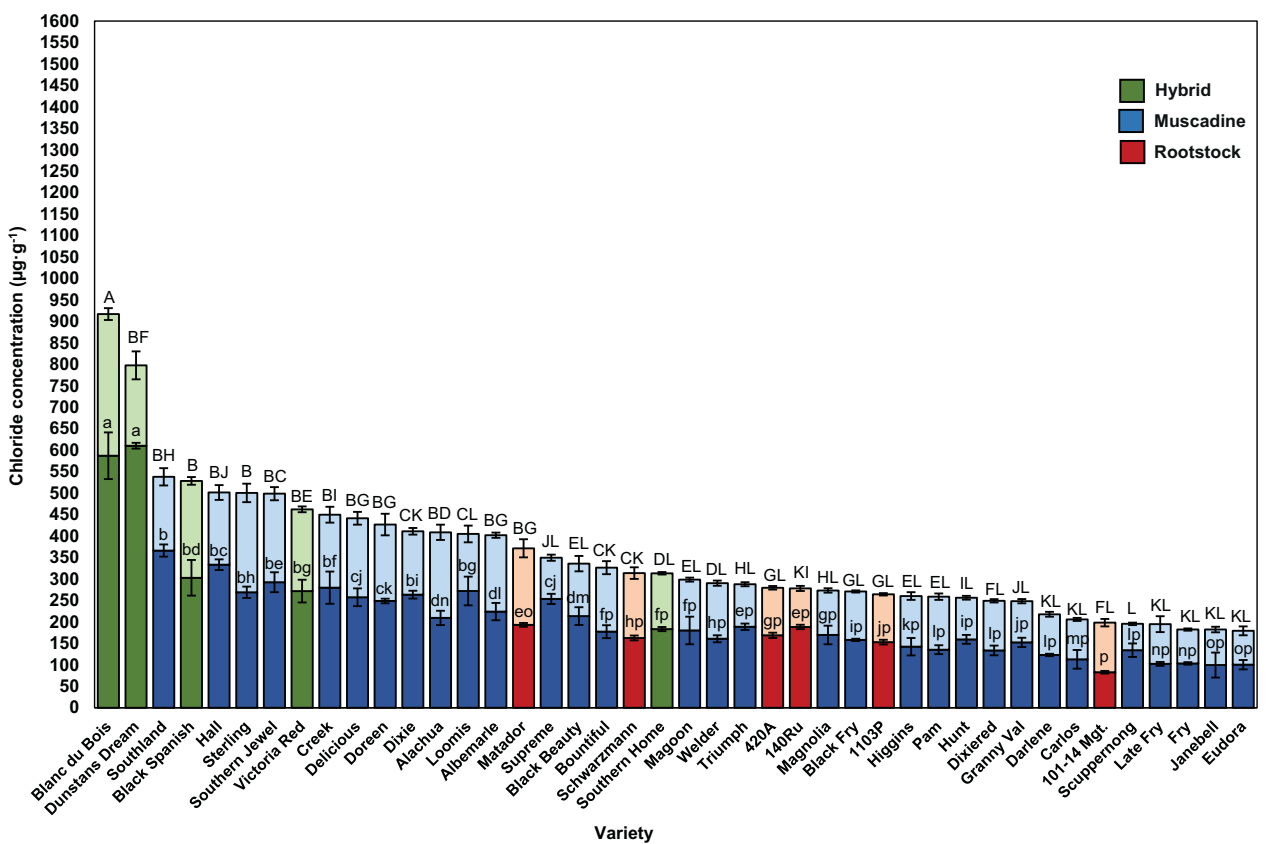

Fig. 2. Chloride concentrations in grape cultivar roots (dark region) and shoots (light region) during greenhouse test 1 after daily irrigation with a $25-\mathrm{mm}$ sodium chloride salt solution for $14 \mathrm{~d}$. Values are mean \pm SE. Top error bars indicate shoot values. Means indicated by different letters are significantly different at $P \leq 0.001$ via Tukey's honestly significant difference test; $1 \mu \mathrm{g} \cdot \mathrm{g}^{-1}=1 \mathrm{ppm}$. 


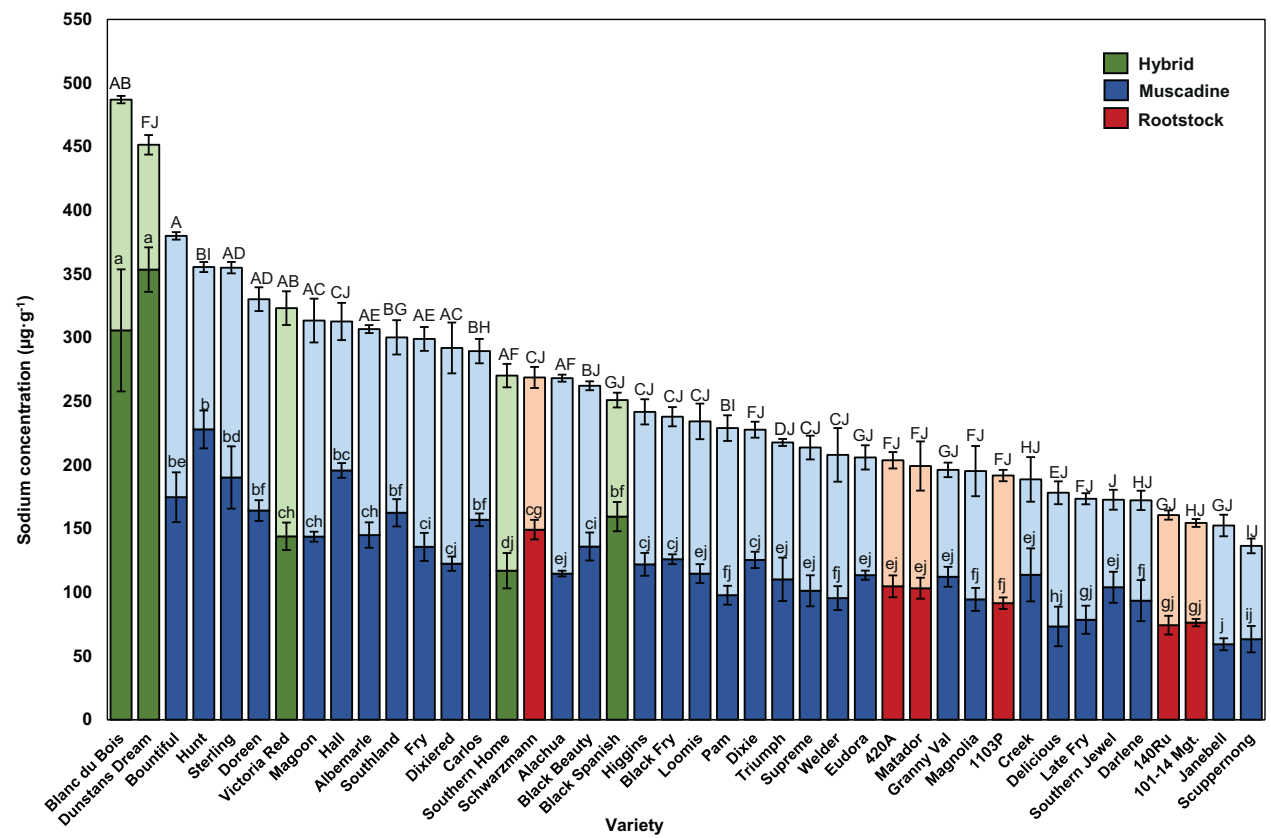

Fig. 3. Sodium concentrations in grape cultivar roots (shaded region) and shoots (unshaded region) during greenhouse test 2 after daily irrigation with a $25-\mathrm{mm}$ sodium chloride salt solution for $14 \mathrm{~d}$. Values are mean $\pm \mathrm{SE}$. Top error bars indicate shoot values. Means indicated by different letters are significantly different at $P \leq 0.001$ via Tukey's honestly significant difference test; $1 \mu \mathrm{g} \cdot \mathrm{g}^{-1}=1 \mathrm{ppm}$.

occur. However, root age and root type could be a factor that we were unable to consider. Softwood cuttings were used during this study based on the work conducted by Fort et al. (2013), who determined that grape softwood cuttings provided the most reliable data and results consistent with published field studies compared with hardwood cuttings and dormant bare root grapevines. Although similar, a much weaker relationship $\left[R^{2}=0.17\right.$ and 0.30 , respectively (Supplemental Figs. 3 and 4)] between root and shoot Na concentrations was observed in the muscadines, and no relationship was observed in the winegrape group (Supplemental Figs. 5 and 6). In contrast, stronger correlations were observed for root and shoot $\mathrm{Cl}$ in the muscadine group $\left[R^{2}=\right.$ 0.58 and 0.39 , respectively (Supplemental Figs. 7 and 8)], whereas very weak correlations were observed for the rootstocks $\left[R^{2}=0.11,0.06,0.39\right.$, and

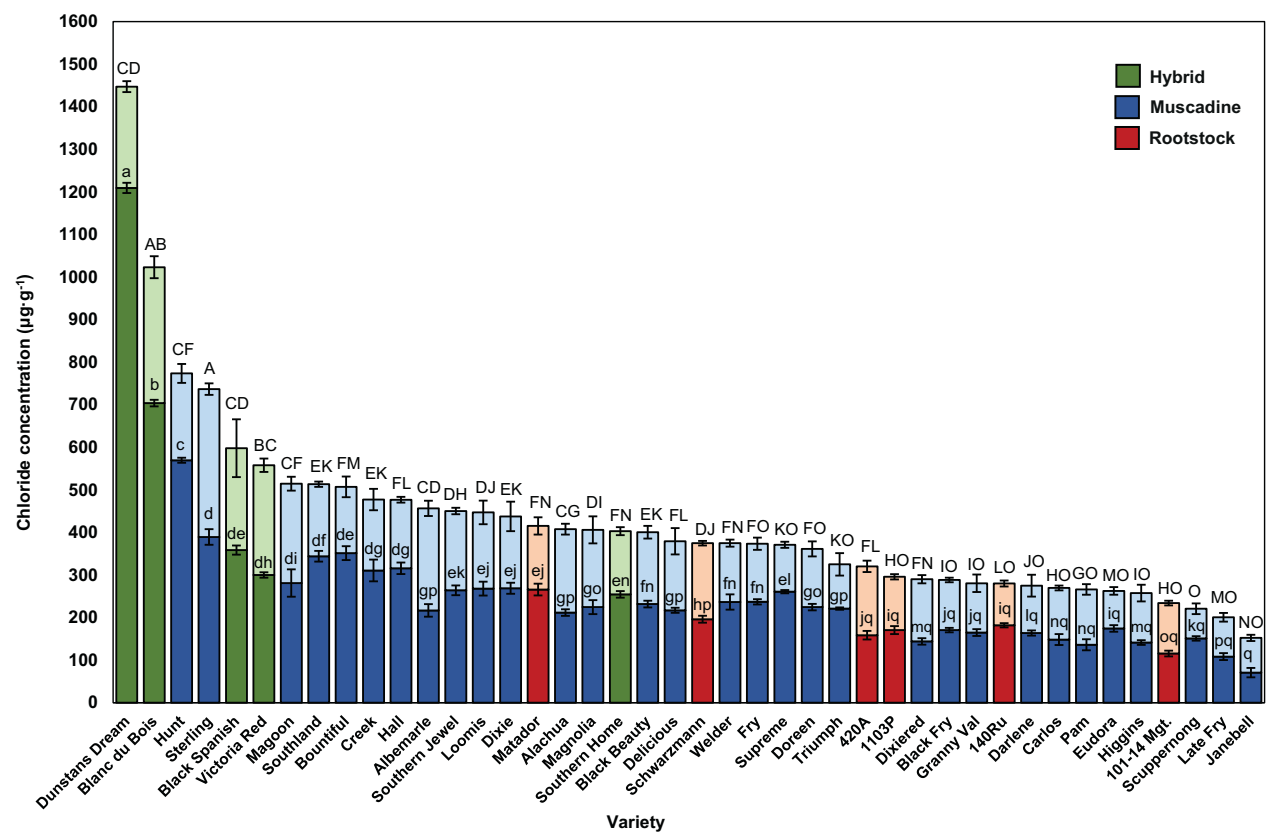

Fig. 4. Chloride concentrations in grape cultivar roots (shaded region) and shoots (unshaded region) during greenhouse test 2 after daily irrigation with a $25-\mathrm{mm}$ sodium chloride salt solution for $14 \mathrm{~d}$. Values are mean \pm SE. Top error bars indicate shoot values. Means indicated by different letters are significantly different at $P \leq 0.001$ via Tukey's honestly significant difference test; $1 \mu \mathrm{g} \cdot \mathrm{g}^{-1}=1 \mathrm{ppm}$. 
Table 2. Mean ratios of root-to-shoot sodium ( $\mathrm{Na}$ ) and chloride $(\mathrm{Cl})$ concentrations of grape cultivars during greenhouse tests 1 and 2 after daily irrigation with a 25-mM sodium chloride salt solution for $14 \mathrm{~d}$.

\begin{tabular}{|c|c|c|}
\hline \multirow[b]{2}{*}{ Cultivar } & $\mathrm{Na}$ & $\mathrm{Cl}$ \\
\hline & \multicolumn{2}{|c|}{ (root:shoot ratio) } \\
\hline Dunstan's Dream & $2.25 \mathrm{a}^{\mathrm{z}}$ & $3.70 \mathrm{a}$ \\
\hline Black Spanish & $1.61 \mathrm{ab}$ & $1.47 \mathrm{~cd}$ \\
\hline Hall & $1.47 \mathrm{bc}$ & $1.90 \mathrm{bd}$ \\
\hline Creek & $1.46 \mathrm{bd}$ & $1.86 \mathrm{bd}$ \\
\hline Dixie & 1.39 be & $1.61 \mathrm{bd}$ \\
\hline Granny Val & 1.30 be & $1.58 \mathrm{bd}$ \\
\hline Welder & 1.30 be & $1.93 \mathrm{bc}$ \\
\hline Southern Jewel & 1.25 be & $1.59 \mathrm{bd}$ \\
\hline Carlos & 1.24 be & $1.29 \mathrm{~cd}$ \\
\hline Hunt & 1.20 be & $1.95 \mathrm{bc}$ \\
\hline Schwarzmann & 1.18 be & $1.22 \mathrm{~cd}$ \\
\hline Matador & 1.18 be & $1.40 \mathrm{~cd}$ \\
\hline Magoon & 1.17 be & $1.39 \mathrm{~cd}$ \\
\hline Higgins & 1.15 be & $1.50 \mathrm{~cd}$ \\
\hline Loomis & 1.15 be & $1.84 \mathrm{bd}$ \\
\hline Southland & 1.12 be & $2.00 \mathrm{bc}$ \\
\hline Blanc du Bois & 1.11 be & $1.87 \mathrm{~cd}$ \\
\hline Black Fry & 1.07 be & $1.60 \mathrm{bd}$ \\
\hline Supreme & 1.05 be & $2.50 \mathrm{~b}$ \\
\hline Black Beauty & 1.05 be & $1.59 \mathrm{bd}$ \\
\hline Eudora & 1.04 be & $1.68 \mathrm{bd}$ \\
\hline Darlene & 0.98 be & $1.41 \mathrm{~cd}$ \\
\hline Triumph & 0.95 be & $2.08 \mathrm{bc}$ \\
\hline Doreen & 0.95 be & $1.53 \mathrm{bd}$ \\
\hline Fry & 0.95 be & $1.53 \mathrm{bd}$ \\
\hline Late Fry & 0.94 be & $1.21 \mathrm{~cd}$ \\
\hline Scuppernong & 0.94 be & $2.09 \mathrm{bc}$ \\
\hline Magnolia & 0.93 be & $1.35 \mathrm{~cd}$ \\
\hline Millardet et de Grasset $420 \mathrm{~A}$ & 0.92 be & $1.30 \mathrm{~cd}$ \\
\hline Paulsen 1103 & 0.92 be & $1.36 \mathrm{~cd}$ \\
\hline Sterling & 0.91 be & $1.25 \mathrm{~cd}$ \\
\hline Albemarle & 0.90 be & $1.14 \mathrm{~cd}$ \\
\hline Victoria Red & 0.87 be & $1.26 \mathrm{~cd}$ \\
\hline Millardet et de Grasset 101-14 & 0.86 ce & $0.92 \mathrm{~d}$ \\
\hline Bountiful & 0.85 ce & $1.57 \mathrm{bd}$ \\
\hline Ruggeri 140 & 0.82 ce & $1.95 \mathrm{bc}$ \\
\hline Dixiered & 0.81 ce & $1.18 \mathrm{bd}$ \\
\hline Alachua & 0.78 ce & $1.11 \mathrm{~cd}$ \\
\hline Janebell & 0.74 ce & $1.13 \mathrm{~cd}$ \\
\hline Delicious & $0.72 \mathrm{de}$ & $1.39 \mathrm{~cd}$ \\
\hline Pam & $0.70 \mathrm{e}$ & $1.23 \mathrm{~cd}$ \\
\hline Southern Home & $0.67 \mathrm{e}$ & $1.50 \mathrm{~cd}$ \\
\hline Significance & $* * *$ & $* * *$ \\
\hline Cultivar $\times$ test & NS & NS \\
\hline
\end{tabular}

0.11 , respectively (Supplemental Figs. 9-12)], suggesting that compartmentalization may have occurred differentially by subgenera. However, as previously discussed, it is unknown how root age and type influence compartmentalization, and it is unknown whether the durations of the salt treatments were sufficient to properly test during our experiments, they generally displayed less leaf necrosis (Figs. 5 and 6 ). When data were pooled into three groups based on type (muscadines, rootstocks, hybrid winegrapes), the muscadine group had less overall leaf necrosis than the rootstocks during both experiments (Table 3 ). This could be explained as a lower sensitivity to $\mathrm{Cl}$ in leaf tissue, which has been reported for salt-tolerant plants (Munns and Gilliham, 2015); however, more work is necessary to confirm this. Although the level of necrosis expressed by each group was consistent across both greenhouse tests, shoot $\mathrm{Na}$ and $\mathrm{Cl}$ did not correlate with necrosis ratings, possibly because of the low resolution of the 5point scale used to assess necrosis. However, the results observed by type were consistent with those of previous research (Baneh et al., 2014; Fort et al., 2013) indicating individual differences in $\mathrm{Cl}$ toxicity among grape species and other accessions as determined by leaf necrosis. For rootstocks, this characteristic may be of little importance because exclusion from shoots would confer salt tolerance.

As a group, there were few differences in overall salt exclusion among the six rootstocks studied, in agreement with the findings of Fort et al. (2013) for 'Schwarzmann', 101-14 Mgt., $1103 \mathrm{P}$, and $140 \mathrm{Ru}$. When compared with many of the muscadine cultivars, these rootstocks did not display superior exclusion of $\mathrm{Na}$ or $\mathrm{Cl}$ at the root level or shoot level, although 1103P, $140 \mathrm{Ru}$, and 'Schwarzmann' are regarded as superior salt excluders among bunch grape rootstocks (Fisarakis et al., 2001; Southey, 1992; Walker et al., 2010). Several of the most effective Clexcluding muscadines ('Scuppernong', 'Janebell', and 'Eudora') contained less $\left(\right.$ mean $\left.=80.9 \mu \mathrm{g} \cdot \mathrm{g}^{-1}\right)$ shoot tissue $\mathrm{Cl}$ during both experiments compared with the most effective $\mathrm{Cl}$-excluding rootstocks 101-14 Mgt. and 140Ru $\left(\right.$ mean $\left.=105.5 \mu \mathrm{g} \cdot \mathrm{g}^{-1}\right)$. In contrast, the muscadine cultivar Sterling contained an average shoot $\mathrm{Cl}$ concentration that was approximately three-times $\left(290 \mu \mathrm{g} \cdot \mathrm{g}^{-1}\right)$ higher during both experiments. This overall wide range of exclusion among muscadine cultivars could be significant because it relates to potential use as rootstocks or for future breeding efforts. It may be noteworthy that the majority of the most effective salt-excluding muscadine cultivars share 


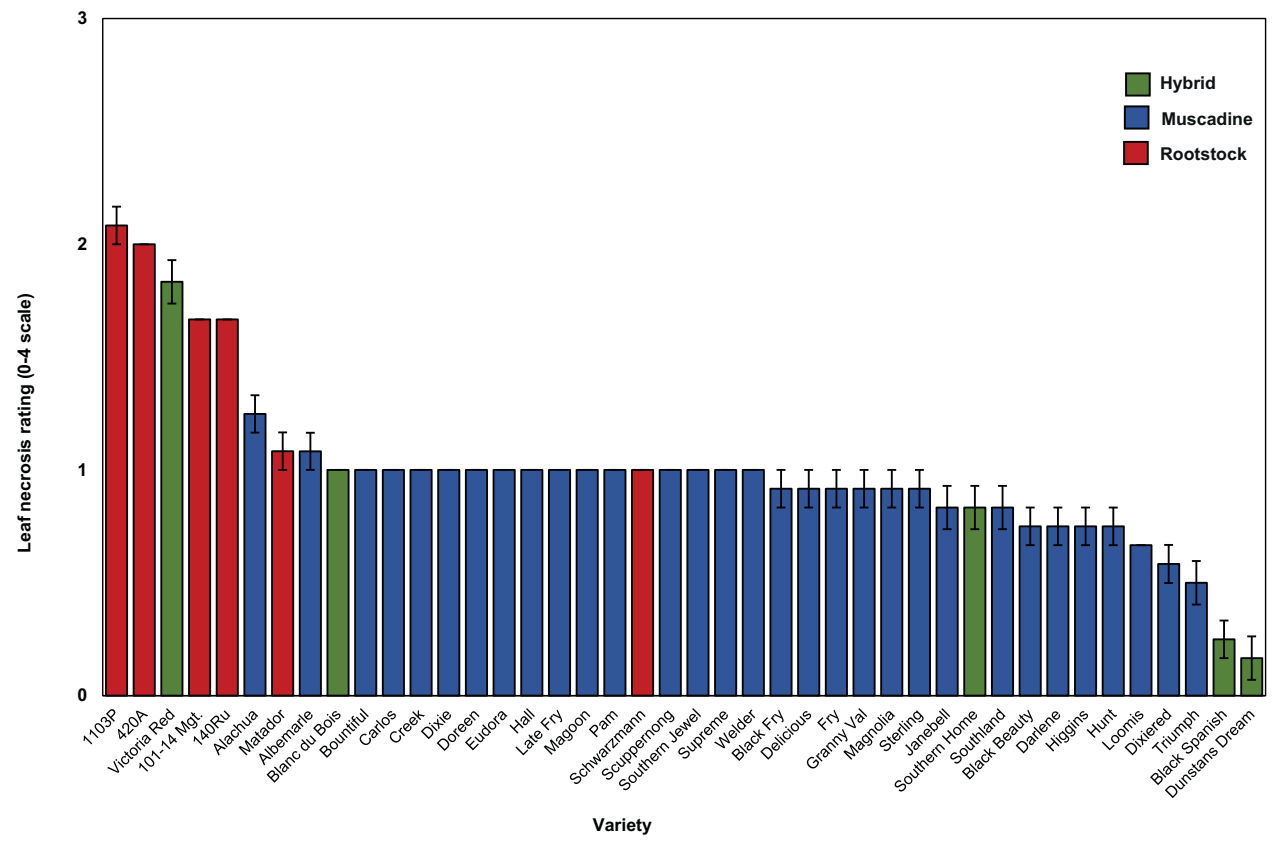

Fig. 5. Leaf necrosis ratings of grape cultivars after daily irrigation with a $25-\mathrm{mm}$ sodium chloride salt solution for $14 \mathrm{~d}$. Values are mean $\pm \mathrm{SE} .0=$ asymptomatic; $1=1 \%$ to $25 \%$ of all leaves displaying any amount of necrosis symptoms; $2=26 \%$ to $50 \% ; 3 b=51 \%$ to $75 \%$; and $4 b=76 \%$ to $100 \%$.

common parentage (Scuppernong). 'Scuppernong' is a wild selection found in Tyrell County, NC, before 1760 (Dearing, 1938). Although unconfirmed, its coastal origin may have resulted in some degree of salt tolerance.

'Blanc Du Bois', the most widely grown white winegrape in Texas (U.S. Department of Agriculture, 2019), maintained higher root and shoot $\mathrm{Na}$ and $\mathrm{Cl}$ concentrations than the six rootstocks in our study. This is consistent with the findings of Scheiner et al. (2020), who reported more than $400 \%$ higher tissue $\mathrm{Na}$ in own-rooted 'Blanc $\mathrm{Du}$ Bois' compared with 'Blanc Du Bois' grafted on 1103P, and of Hillin et al. (202l), who observed a more than $300 \%$ difference between leaf $\mathrm{Cl}$ of own-rooted 'Blanc Du Bois' and
1103P. The average concentration shoot $\mathrm{Cl}$ in 'Blanc Du Bois' was more than double that of the six rootstocks. This may be significant because 'Blanc Du Bois' is most commonly grown on its own roots, and these data suggest that grafting onto a rootstock would be beneficial if $\mathrm{Na}$ or $\mathrm{Cl}$ is present in the soil or irrigation water at concentrations that would inhibit normal growth.

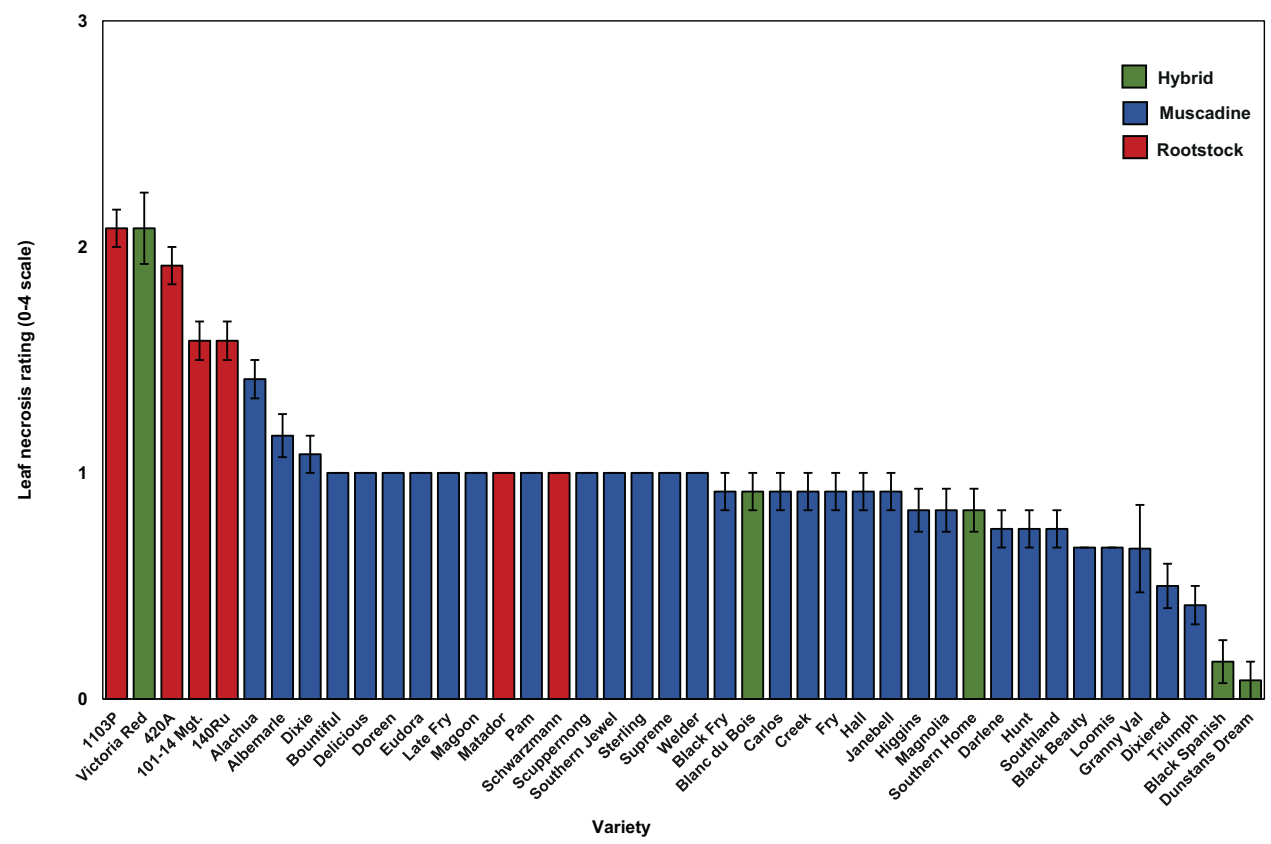

Fig. 6. Leaf necrosis ratings of grape cultivars after daily irrigation with a 25-mM sodium chloride salt solution for $14 \mathrm{~d}$. Values are mean $\pm \mathrm{SE} .0$ asymptomatic; $1=1 \%$ to $25 \%$ of all leaves displaying any amount of necrosis symptoms; $2=26 \%$ to $50 \% ; 3=51 \%$ to $75 \%$; and $4=76 \%$ to $100 \%$. 
Table 3. Kruskal-Wallis inclusive and pairwise comparisons of mean necrosis ratings for muscadines, rootstocks, and hybrid winegrapes after daily irrigation with a 25-mM sodium chloride salt solution for $14 \mathrm{~d}$.

\begin{tabular}{|c|c|c|c|c|}
\hline & Mean & df & Chi-square & $P>\chi^{2}$ \\
\hline \multicolumn{5}{|c|}{ Test 1} \\
\hline Kruskal-Wallis & 0.99 & 2 & 12.32 & $0.0021 * * *$ \\
\hline Muscadines vs. rootstocks & 1.02 & 1 & 12.60 & $0.0004 * * *$ \\
\hline Muscadines vs. winegrapes & 0.89 & 1 & 0.62 & 0.4318 \\
\hline Rootstocks vs winegrapes & 1.23 & 1 & 3.71 & 0.0541 \\
\hline \multicolumn{5}{|c|}{ Test 2} \\
\hline Kruskal-Wallis & 0.98 & 2 & 10.31 & $0.0058 * * *$ \\
\hline Muscadines vs. rootstocks & 1.00 & 1 & 10.14 & $0.0015 * * *$ \\
\hline Muscadines vs. winegrapes & 0.89 & 1 & 1.37 & 0.2421 \\
\hline Rootstocks vs. winegrapes & 1.20 & 1 & 2.71 & 0.0996 \\
\hline
\end{tabular}

*** indicates statistically significant at the 0.001 level of probability.

\section{Conclusions}

Grapes are characterized as moderately salt-tolerant, and salt-tolerant rootstocks are often recommended for bunch grapes when salinity is a limiting factor. Rootstocks that are characterized as salt-tolerant more effectively exclude salt ions from shoot tissue. This study used an established greenhouse screening procedure to compare the salt exclusion capacity of 31 muscadine grape and five interspecific winegrape cultivars to that of six bunch grape rootstocks. During two experiments, there was no clear difference among the salt-exclusion potential of muscadine and bunch grape rootstocks. However, the wide range in exclusion across muscadines suggests the potential for using specific muscadine cultivars as rootstocks when salinity is a limiting factor. The hybrid white winegrape 'Blanc Du Bois' consistently accumulated $\mathrm{Na}$ and $\mathrm{Cl}$ concentrations more than double those of the bunch grape rootstocks, indicating that it has a relatively poor capacity to exclude salts but only displayed moderate leaf necrosis.

\section{Literature cited}

Ahmad, R. and M.A. Anjum. 2020. Physiological and molecular basis of salinity tolerance in fruit crops, p. 445-464. In: A.K. Srivastava and C. Hu (eds.). Fruit crops diagnosis and management of nutrient constraints. Elsevier, Amsterdam, Netherlands. https://doi.org/10.1016/B978-012-818732-6.00032-0.

Antcliff, A.J., H.P. Newman, and H.C. Barrett. 1983. Variation in chloride accumulation in some American species of grapevine. Vitis 22:357-362.
Ayars, J.E. 2013. Adapting irrigated agriculture to drought in the San Joaquin Valley of California, p. 25-39. In: K. Schwabe, J. Albiac, J. Connor, R. Hassan, and L. Meza González (eds.). Drought in arid and semi-arid regions. Springer, Dordrecht, Netherlands. https://doi.org/ 10.1007/978-94-007-6636-5_2.

Baneh, H.D., A. Hassani, and F.G. Shaieste. 2014. Effects of salinity on leaf mineral composition and salt injury symptoms of some Iranian wild grapevine (Vitis vinifera L. ssp. sylvestris) genotypes. OENO One 48:231235, https://doi.org/10.20870/oenoone.2014.48.4.1692.

Bernstein, L., C.F. Ehlig, and R.A. Clark. 1969. Effect of grape rootstocks on chloride accumulation in leaves. J. Amer. Soc. Hort. Sci. 94:584-590.

Clark, J.R. 1997. Grapes, p. 248-299. In: R.M. Brooks and H.P. Olmo (eds.). Brooks and Olmo register of fruit \& nut varieties. 3rd ed. ASHS Press, Alexandria, VA.

Cousins, P. 2005. Evolution, genetics, and breeding: Viticultural applications of the origins of our rootstocks, p. 1-7. In: P. Cousins, and R.K. Striegler (eds.). Grapevine rootstocks: Current use, research and application. U.S. Dept. Agr., Agr. Res. Serv., Plant Genet. Resour. Unit, Osage Beach, MO.

Das, P. and A.L. Majumder. 2019. Transcriptome analysis of grapevine under salinity and identification of key genes responsible for salt tolerance. Funct. Integr. Genomics 19:61-73, https://doi.org/ 10.1007/s10142-018-0628-6.

Dearing, C. 1938. Muscadine grapes. U.S. Dept. Agr. Farmers' Bul. 1785.

Downton, W.J.S. 1977a. Influence of rootstocks on the accumulation of chloride, sodium and potassium in grapevines. Aust. J. Agr. Res. 28:879-889, https:// doi.org/10.1071/AR9770879.
Downton, W.J.S. 1977b. Chloride accumulation in different species of grapevine. Scientia Hort. 7:249-253, https://doi.org/ 10.1016/0304-4238(77)90021-8.

Ehlig, C.F. 1960. Effects of salinity on four varieties of table grapes grown in sand culture. Proc. Amer. Soc. Hort. Sci. 76: 323-331.

Fisarakis, I., K. Chartzoulakis, and D. Stavrakas. 2001. Response of Sultana vines ( $V$. vinifera L.) on six rootstocks to $\mathrm{NaCl}$ salinity exposure and recovery. Agr. Water Manage. 51:13-27, https://doi.org/ 10.1016/S0378-3774(01)00115-9.

Fort, K.P., K.M. Lowe, W.A. Thomas, and M.A. Walker. 2013. Cultural conditions and propagule type influence relative chloride exclusion in grapevine rootstocks. Amer. J. Enol. Viticult. 64:241-250, https://doi. org/10.5344/ajev.2013.12073.

Fort, K.P. and M.A. Walker. 2008. Breeding salinity tolerant grape rootstocks. In: Proc. 2nd Annu. Vitic. Res. Conf., Univ. California, Davis. p. 11.

George, P.G., R.E. Mace, and R. Petrossian. 2011. Aquifers of Texas. Texas Water Dev. Board Rpt. 380.

Gilliham, M. and M. Tester. 2005. The regulation of anion loading to the maize root xylem. Plant Physiol. 137:819-828, https:// doi.org/10.1104/pp.104.054056.

Heinitz, C.C., K. Fort, and M.A. Walker. 2014. Developing drought and salt resistant grape rootstocks. Acta Hort. 1082:305312, https://doi.org/10.17660/ActaHortic. 2015.1082.42.

Henderson, S.W., U. Baumann, D.H. Blackmore, A.R. Walker, R.R. Walker, and M. Gilliham. 2014. Shoot chloride exclusion and salt tolerance in grapevine is associated with differential ion transporter expression in roots. BMC Plant Biol. 14: 1-18, https://doi.org/10.1186/s12870014-0273-8.

Hickinbotham, A.R. 1933. Soluble salts in non-irrigated vineyards. Dept. Agr. South Aust. Bul. 279.

Hillin, D., P. Helwi, and J. Scheiner. 2021. Tolerance of muscadine grapes (Muscadinia rotundifolia) to alkaline soil. OENO One 55:227-238, https://doi.org/10.20870/ oeno-one.2021.55.2.3387.

Iseki, K., R. Marubodee, H. Ehara, and N. Tomooka. 2017. A rapid quantification method for tissue $\mathrm{Na}+$ and $\mathrm{K}+$ concentrations in salt-tolerant and susceptible accessions in Vigna vexillata (L.) A. Rich. Plant Prod. Sci. 20:144-148, https://doi.org/ 10.1080/1343943X.2016.1251826.

McEAlexander, D. and J.G. Obbink. 1971. Effect of chloride in solution culture on growth and chloride uptake of Sultana 
and Salt Creek grape vines. Aust. J. Exp. Agr. 11:357-361.

Munns, R. and M. Tester. 2008. Mechanisms of salinity tolerance. Annu. Rev. Plant Biol. 59:651-681, https://doi.org/ 10.1071/EA9710357.

Munns, R. and M. Gilliham. 2015. Salt tolerance of crops - What's the cost? New Phytol. 208:668-673, https://doi.org/ $10.1111 /$ nph.13519.

Munns, R., D.A. Day, W. Fricke, M. Watt, B. Arsova, B.J. Barkla, J. Bose, C.S. Byrt, Z.H. Chen, K.J. Foster, and M. Gilliham. 2020. Energy costs of salt tolerance in crop plants. New Phytol. 225:1072-1090.

Prior, L.D., A.M. Grieve, and B.R. Cullis. 1992. Sodium chloride and soil texture interactions in irrigated field grown Sultana grapevines I. Yield and fruit quality. Aust. J. Agr. Res. 43:1051-1066, https://doi. org/10.1071/AR9921051.

Qadir, M., E. Quillérou, V. Nangia, G. Murtaza, M. Singh, R.J. Thomas, P. Drechsel, and A.D. Noble. 2014. Economics of saltinduced land degradation and restoration. Nat. Resour. Forum 38:282-295, https:// doi.org/10.1111/1477-8947.12054.

Riaz, S., A.C. Tenscher, B.P. Smith, D.A. $\mathrm{Ng}$, and M.A. Walker. 2008. Use of SSR markers to assess identity, pedigree, and diversity of cultivated muscadine grapes. J. Amer. Soc. Hort. Sci. 133:559-568, https://doi. org/10.21273/JASHS.133.4.559.
Scheiner, J.J., A. Labay, and J. Kamas. 2020. Rootstocks improve Blanc Du Bois vine performance and fruit quality on alkaline soil. Catalyst Discovery Into Practice 4:63-73, https://doi.org/10.5344/ catalyst.2020.19007.

Sauer, M.R. 1968. Effects of vine rootstocks on chloride concentration in Sultana scions. Vitis 7:223-226.

Southey, J.M. 1992. Grapevine rootstock performance under diverse conditions in South Africa, p. 27-51. In: J.A. Wolpert, M.A. Walker, and E. Weber (eds.). Proc. Rootstock Seminar: A worldwide perspective. Amer. Soc. Enol. Vitic., Reno, NV.

Sykes, S.R. 1985. Variation in chloride accumulation by hybrid vines from crosses involving the cultivars Ramsey, Villard Blanc, and Sultana. Amer. J. Enol. Viticult. 36:30-37.

Sykes, S.R. 1987. Variation in chloride accumulation in hybrids and backcrosses of Vitis berlandieri and Vitis vinifera under glasshouse conditions. Amer. J. Enol. Viticult. 38:313-320.

Teakle, N.L. and S.D. Tyerman. 2010. Mechanisms of Cl- transport contributing to salt tolerance. Plant Cell Environ. 33:566-589, https://doi.org/10.1111/ j.1365-3040.2009.02060.x.

Thomas, W.A. 2011. Development of a repeatable, low-cost, high-throughput and precise salt tolerance assay for grapevines. Univ. California Press, Davis, CA.
U.S. Department of Agriculture. 2019. Texas wine grape varieties. U.S. Dept. Agr., Washington, DC.

Volkmar, K.M., Y. Hu, and H. Steppuhn. 1998. Physiological responses of plants to salinity: A review. Can. J. Plt. Sci. 78:19-27, https://doi.org/10.4141/P97-020.

Walker, R.R., D.H. Blackmore, P.R. Clingeleffer, and R.L. Correll. 2008. Rootstock effects of salt tolerance of irrigated field-grown grapevines (Vitis vinifera L. cv. Sultana) 1. Yield and vigour inter-relationships. Aust. J. Grape Wine Res. 8:3-14, https://doi.org/10.1111/ j.1755-0238.2002.tb00206.x.

Walker, R.R., D.H. Blackmore, and P.R. Clingeleffer. 2010. Impact of rootstock on yield and ion concentrations in petioles, juice and wine of Shiraz and Chardonnay in different viticultural environments with different irrigation water salinity. Aust. J. Grape Wine Res. 16:243-257, https://doi.org/ 10.1111/j.1755-0238.2009.00081.x.

Winkler, A.J., J.A. Cook, W.M. Kliewer, and L.A. Lider. 1974. General viticulture. Univ. California Press, Berkeley, CA. https://doi.org/10.1097/00010694-19 7512000-00012.

Zelm, E., Y. Zhang, and C. Testerink. 2020. Salt tolerance mechanisms of plants. Annu. Rev. Plant Biol. 71:403-433, https://doi.org/10.1146/annurev-arplant050718-100005. 


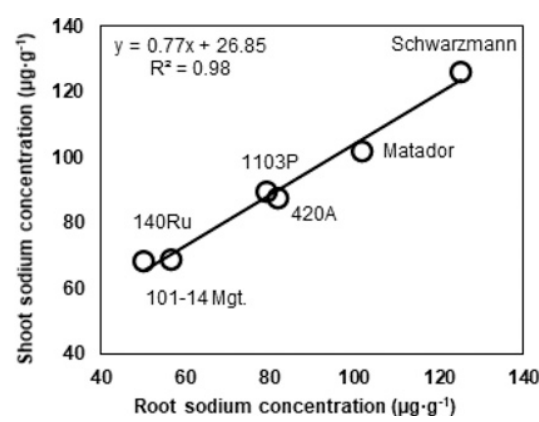

Supplemental Fig. 1. Correlations among sodium concentrations in root and shoot tissues of six rootstock grape cultivars during greenhouse test 1 after daily irrigation with a $25-\mathrm{mM}$ sodium chloride salt solution for $14 \mathrm{~d}$; $1 \mu \mathrm{g} \cdot \mathrm{g}^{-1}=1 \mathrm{ppm}$.

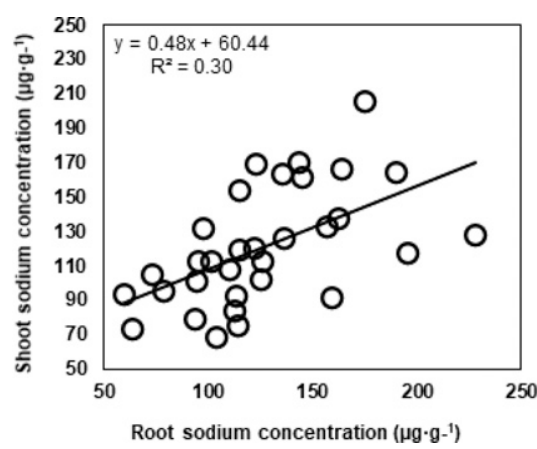

Supplemental Fig. 4. Correlations among sodium concentrations in root and shoot tissues of five winegrape cultivars during greenhouse test 2 after daily irrigation with a $25-\mathrm{mM}$ sodium chloride salt solution for $14 \mathrm{~d}$; $1 \mu \mathrm{g} \cdot \mathrm{g}^{-1}=1 \mathrm{ppm}$.

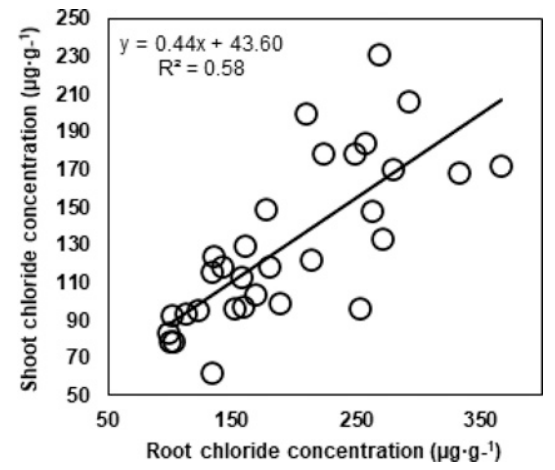

Supplemental Fig. 7. Correlations among chloride concentrations in root and shoot tissues of six rootstock grape cultivars during greenhouse test 1 after daily irrigation with a $25-\mathrm{mm}$ sodium chloride salt solution for $14 \mathrm{~d}$; $1 \mu \mathrm{g} \cdot \mathrm{g}^{-1}=1 \mathrm{ppm}$.

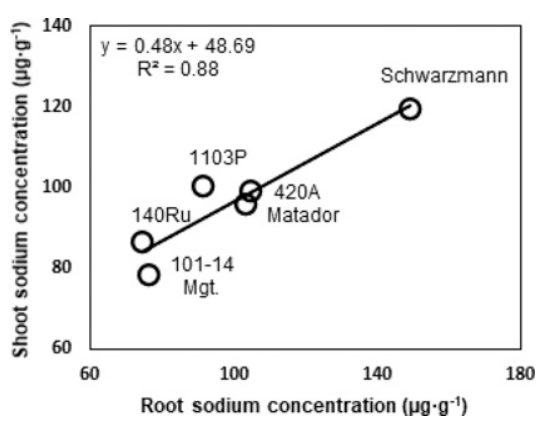

Supplemental Fig. 2. Correlations among sodium concentrations in root and shoot tissues of six rootstock grape cultivars during greenhouse test 2 after daily irrigation with a $25-\mathrm{mm}$ sodium chloride salt solution for $14 \mathrm{~d}$; $1 \mu \mathrm{g} \cdot \mathrm{g}^{-1}=1 \mathrm{ppm}$.

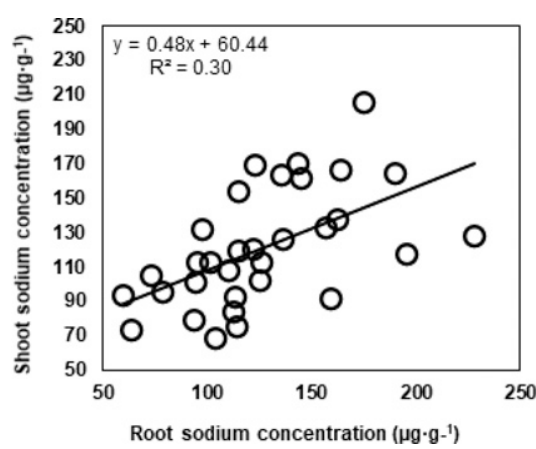

Supplemental Fig. 5. Correlations among sodium concentrations in root and shoot tissues of 31 muscadine cultivars during greenhouse test 1 after daily irrigation with a $25-\mathrm{mm}$ sodium chloride salt solution for $14 \mathrm{~d}$; $1 \mu \mathrm{g} \cdot \mathrm{g}^{-1}=1 \mathrm{ppm}$.

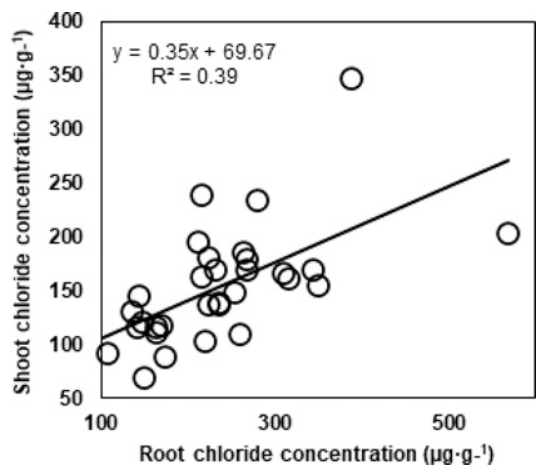

Supplemental Fig. 8. Correlations among chloride concentrations in root and shoot tissue of six rootstock grape cultivars during greenhouse test 2 after daily irrigation with a $25-\mathrm{mM}$ sodium chloride salt solution for $14 \mathrm{~d}$; $1 \mu \mathrm{g} \cdot \mathrm{g}^{-1}=1 \mathrm{ppm}$.

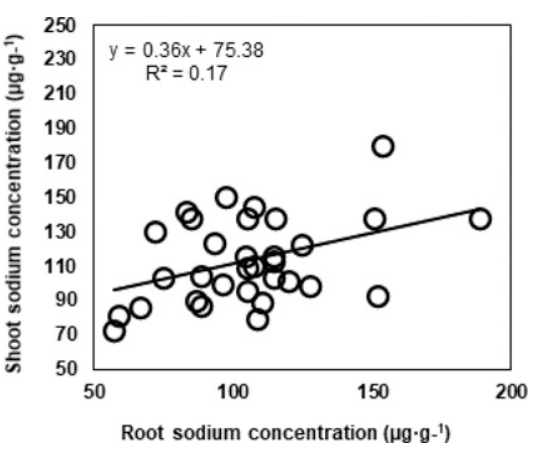

Supplemental Fig. 3. Correlations among sodium concentrations in root and shoot tissues of five winegrape cultivars during greenhouse test 1 after daily irrigation with a $25-\mathrm{mM}$ sodium chloride salt solution for $14 \mathrm{~d}$; $1 \mu \mathrm{g} \cdot \mathrm{g}^{-1}=1 \mathrm{ppm}$.

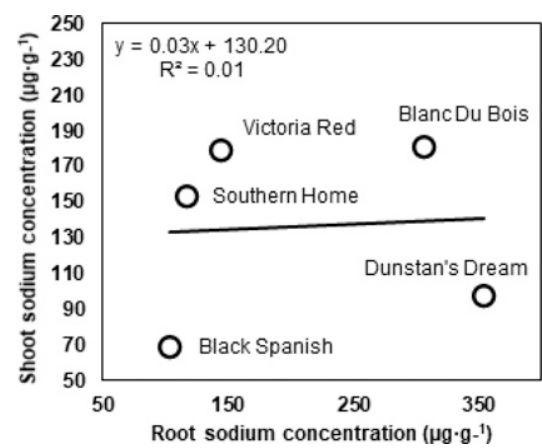

Supplemental Fig. 6. Correlations among sodium concentrations in root and shoot tissues of 31 muscadine cultivars during greenhouse test 2 after daily irrigation with a $25-\mathrm{mm}$ sodium chloride salt solution for $14 \mathrm{~d}$; $1 \mu \mathrm{g} \cdot \mathrm{g}^{-1}=1 \mathrm{ppm}$.

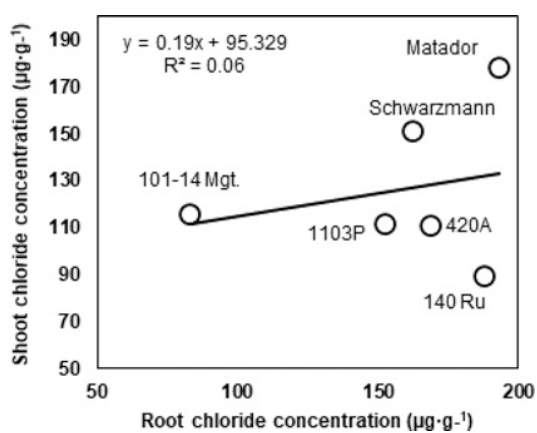

Supplemental Fig. 9. Correlations among chloride concentrations in root and shoot tissues of five winegrape cultivars during greenhouse test 1 after daily irrigation with a 25-mM sodium chloride salt solution for $14 \mathrm{~d}$; $1 \mu \mathrm{g} \cdot \mathrm{g}^{-1}=1 \mathrm{ppm}$. 


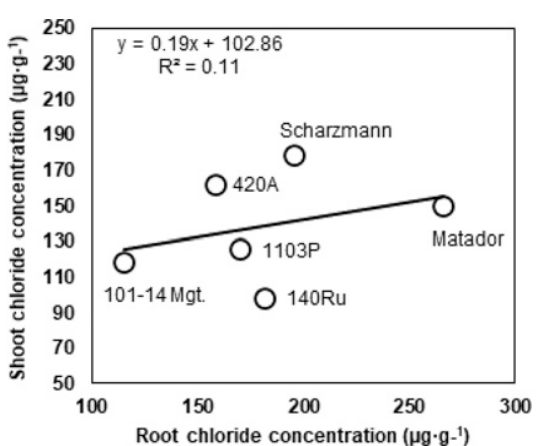

Supplemental Fig. 10. Correlations among chloride concentrations in root and shoot tissues of five winegrape cultivars during greenhouse test 2 after daily irrigation with a $25-\mathrm{mm}$ sodium chloride salt solution for $14 \mathrm{~d}$; $1 \mu \mathrm{g} \cdot \mathrm{g}^{-1}=1 \mathrm{ppm}$.

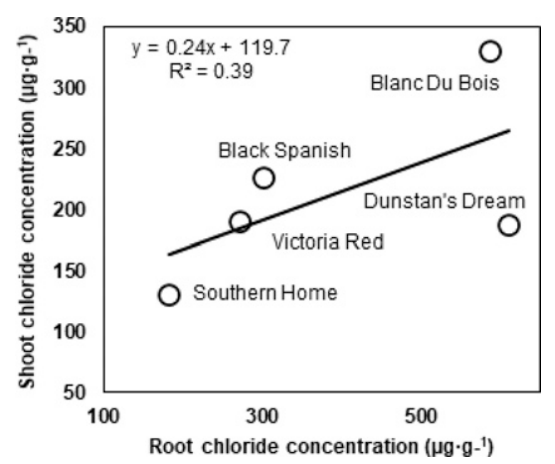

Supplemental Fig. 11. Correlations among chloride concentrations in root and shoot tissues of 31 muscadine cultivars during greenhouse test 1 after daily irrigation with a 25-mM sodium chloride salt solution for $14 \mathrm{~d}$; $1 \mu \mathrm{g} \cdot \mathrm{g}^{-1}=1 \mathrm{ppm}$.

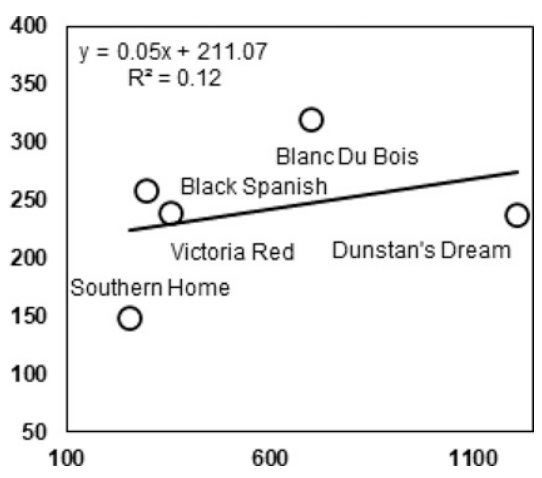

Supplemental Fig. 12. Correlations among chloride concentrations in root and shoot tissues of 31 muscadine cultivars during greenhouse test 2 after daily irrigation with a 25-mM sodium chloride salt solution for $14 \mathrm{~d}$; $1 \mu \mathrm{g} \cdot \mathrm{g}^{-1}=1 \mathrm{ppm}$. 